\title{
Urotensin II Is Raised In Acute Myocardial Infarction And Low Levels Predict Risk Of Adverse Clinical Outcome In Humans
}

Sohail Q. Khan, BSc (Hons), MB ChB, MRCP(UK), Sanjay S. Bhandari, BSc(Hons), Pauline Quinn, MS, Joan E. Davies FRCP, PhD, Leong L. Ng MA, MD, FRCP

University of Leicester

Department of Cardiovascular Sciences

Clinical Sciences Building

Leicester Royal Infirmary

Leicester LE2 7LX, UK

Corresponding author: Dr. Sohail Q. Khan

Department of Cardiovascular Medicine

Clinical Sciences Building

Leicester Royal Infirmary

Leicester LE2 7LX, UK

Phone:+1162523132 ; fax:+1162523108; e-mail:sqk1@le.ac.uk 


\section{Abstract}

Background: UII is elevated in patients with heart failure; however its role in acute myocardial infarction (AMI) is unknown. We sought to compare levels of UII in patients with AMI to controls. We also compared UII to $\mathrm{N}$ terminal pro B type natriuretic peptide (NT-BNP) to evaluate whether levels of UII can be used to predict the risk of adverse clinical outcome (ACO).

Methods and Results 129 patients were studied with serial blood measurements and echocardiogram during their index admission. Plasma concentration of median UII was significantly elevated in AMI compared to controls (median 1.40 vs. $0.42 \mathrm{fmol} / \mathrm{ml} \mathrm{p}<0.012$ ). Over the median follow up of 102 days (range 0-189) there were 14 deaths and 14 readmissions with AMI or heart failure. Using a Cox proportional hazards model the only independent predictors of ACO were UII (OR 0.29, p=0.046) and NT-BNP (OR 4.78, p=0.012) between 73-96hr. The Kaplan-Meier survival curve revealed a significantly better clinical outcome in patients with UII above the median compared with UII below the median. Conclusions UII levels are raised in AMI and is an independent predictor of ACO. Patients with a poor outcome mount a lower UII response suggesting a possible cardioprotective role for this peptide.

Keywords: natriuretic peptide, Myocardial Infarction, cardiovascular disease, prognosis 


\section{Introduction}

Acute myocardial Infarction (AMI) is a leading cause of mortality and morbidity. Recent advances in the treatment of AMI have improved patient survival. However, despite this there is still an appreciable mortality associated with this condition. The challenge remains to try and identify those patients who are deemed to be at high risk of adverse clinical outcome (ACO). Circulating natriuretic peptides certainly provide some information with regard to prognosis following AMI [1,2]. However a multimarker approach may be more informative [3]. We investigated a novel cardiovascular peptide called urotensin II (UII) with homology to the teleost fish hormone [4]. This cyclic undecapeptide is the ligand for an orphan G protein receptor (GPR14), and both peptide and receptors are found within the cardiovascular system [5]. UII has potent vasoactive properties, which appear to be variable and dependent on the vascular bed. UII causes potent vasoconstriction in rat thoracic aorta [4], whereas it caused potent vasodilatation in human pulmonary vasculature and abdominal resistance vessels [6]. UII has a cardiostimulatory action as it mediates a positive inotropic effect in human atrium [7]. Recently it has been found to be elevated in heart failure irrespective of age, sex, or NYHA class which suggests a pathophysiological role for this peptide in this disease state [8]. The aims of the study were to establish the secretory patterns in the acute phase of AMI and to investigate whether UII levels could be used as a prognostic marker in combination with $\mathrm{N}$ terminal proB type natriuretic peptide (NT-BNP) in AMI patients.

\section{Materials and Methods}

\section{Study population}

We studied 129 patients admitted to the Coronary Care Unit of Leicester Royal Infirmary. The study complied with the Declaration of Helsinki, was approved by the local ethics committee and written informed consent was obtained from patients. AMI was defined at presentation with at least two of three standard criteria, i.e. appropriate symptoms, acute ECG changes of 
infarction (ST elevation or depression, new left bundle branch block) and a rise in troponin T above the $99^{\text {th }}$ centile for our population. AMI was sub categorised into ST segment elevation myocardial infarction (STEMI) or non-ST segment myocardial infarction (NSTEMI). Control subjects were age and gender matched and recruited from University of Leicester.

\section{Plasma Samples}

Serial blood measurements were made at 0-24, 25-48, 49-72, 73-96, 97-120 hr after onset of chest pain for determination of plasma UII and N-BNP. After 15 minutes bed rest, 20mL blood was collected into tubes containing EDTA and aprotinin. Plasma was stored at $-70^{\circ} \mathrm{C}$ until assayed and all analysis was done in a single batch.

\section{Echocardiography}

Transthoracic echocardiography was performed in patients using a Sonos 5500 instrument (Philips Medical Systems). A 16-segment left ventricular wall motion index (LVWMI) based on the American Society of Echocardiography model [9] was derived by scoring each LV segment (1=normal, 2=hypokinesis, 3=akinesis and 4=dyskinesis (Paradoxical Motion), and dividing the total by the number of segments scored. Left ventricular ejection fraction (LVEF) was calculated using the biplane method of discs formula [9].

\section{NT-BNP Assay}

Our NT-BNP assay was based on a non-competitive assay [10]. Sheep antibodies were raised to the N-terminal of human NT-BNP and monoclonal mouse antibodies were raised to the Cterminal. The N-terminal IgG was affinity-purified and biotinylated. Samples or NT-BNP standards were incubated in C-terminal IgG-coated wells with the biotinylated antibody for 24 hours at $4^{\circ} \mathrm{C}$. Detection was with methyl-acridinium ester (MAE)-labelled streptavidin [11]. 
The lower limit of detection was $0.3 \mathrm{fmol} / \mathrm{mL}$. There was no cross reactivity with atrial natriuretic peptide, BNP, or C-type natriuretic peptide.

\section{Urotensin II Assay}

Stored plasma samples were extracted using $\mathrm{C}_{18}$ Sep-Pak column cartridges and redissolved in assay buffer for measurement of UII Antibody specific for UII was obtained from Bachem, St. Helens, Merseyside, U.K. Biotinylated UII purified on reverse-phase high pressure liquid chromatography served as the tracer. A competitive assay with $\mathrm{C}_{18}$ extracts of plasma was utilized, incubating $50 \mathrm{ng}$ of the antibody with extracts or standards in assay buffer [11]. After 24 hours of incubation at $4^{\circ} \mathrm{C}$, biotinylated UII tracer was added (250 fmol/well). Immunoprecipitates were recovered in anti-rabbit IgG-coated ELISA plates. After washes and incubation with streptavidin-MAE, chemiluminescence was elicited as described [11]. The lower limit of detection was $0.29 \mathrm{fmol} / \mathrm{mL}$.

\section{End points}

We assessed the value of both UII and NT-BNP for the prediction of mortality. We used a combined endpoint consisting of mortality, reinfarction, need for urgent revascularisation or readmission to hospital with heart failure. Hospitalization for AMI was defined as above and heart failure was defined as a hospital admission for which heart failure was the primary reason.

\section{Statistical Analysis}

Statistical analyses were performed on SPSS Version 12 (SPSS Inc, Chicago, Illinois). The continuous variables in the two independent groups were compared using the Mann Whitney U test. Spearman's correlations were performed and binary logistic regression analyses were conducted which, included baseline patient characteristics (age, sex, serum creatinine, Killip 
class, territory of AMI and whether the patient received thrombolysis or not) and peptide markers (including troponin I), to test the independent predictive power of the peptides above and below the median for ACO as defined above. In order to identify the independent predictors of ACO the Cox proportional hazard analyses was used. Kaplan Meier survival curves were generated to visualise the relationship between the peptides NT-BNP and UII and the composite endpoints. To compare the predictive value of NT-BNP and UII, receiveroperating characteristic (ROC) curves were generated and the area under the curves (AUC) was calculated. A p value below 0.05 was deemed to be statistically significant. Power calculations suggested that a standardised difference of log transformed UII levels of 0.6 (SD estimated at 0.5 ) could be detected with a power of $80 \%$ at $\mathrm{p}<0.05$ with a sample size of 90 . A larger number was recruited in case some patients were lost to follow-up.

\section{Results}

\section{Patient Characteristics}

The demographic features of the patient population are shown in Table 1. Median length of follow-up was 102 days with a range of 0-189 days. Of the patients enrolled, $64.8 \%$ received thrombolysis during the index admission. No patient was lost to follow-up. During follow-up, 14 (10.8\%) patients died, 14 (10.8\%) were readmitted with heart failure or AMI and 2 (1.6\%) patients required urgent revascularisation in the form of percutaneous coronary intervention. Echocardiographic data was available for 117 (90.7\%) of the 129 patients and done at median of 3.5 days (range 2-5). 10 echocardiograms were unanalysable and 2 patients did not receive an echocardiogram.

\section{UII levels in patients and controls}

Plasma levels of UII in patients with AMI ranged from 0.29-34.50 fmol/ml. Median level over the 5 days was $1.40 \mathrm{fmol} / \mathrm{ml}$. These levels were significantly higher than those observed in the 
control subjects (median $0.42 \mathrm{fmol} / \mathrm{ml}$, range 0.29-4.27 fmol $/ \mathrm{ml}$; $\mathrm{p}=0.012$ ). UII levels were not correlated with peak troponin I levels $(r=0.073, p>0.155)$, age $(r=0.032, p>0.245)$ or LVWMI ( $r=-0.189, \mathrm{p}>0.202)$. UII did not differ significantly according to gender, smoking status, the presence or absence of diabetes mellitus, hypertension, previous MI diagnosis, hypercholesterolemia or whether a patient received thrombolyis or not. The time course of secretion of UII is shown in figure 1. There was no significant difference in UII secretion within the same individual over the 5 days ( $\mathrm{p}>0.05)$.

\section{NT-BNP levels in patients and controls}

NT-BNP was significantly elevated in AMI compared with controls (Median [Range], fmol/ml, 1374.8 [0.3-11485.3] vs. 17.4 [0.3-134.4]; p=0.002) and was significantly higher in patients with an ACO (1003.8 [104.3-11485.3] vs. 360.3 [0.30- 10352.89.4]; $\mathrm{p}=0.015)$. The time course of secretion of NT-BNP revealed a significant difference over the 5 days $(p=0.004)$ and is shown in figure 2.

\section{Relationship between UII and echocardiographic parameters}

For the whole population, mean LVWMI was 1.49 (range 1.08-2.44) and EF was $42.3 \%$. The LVWMI score in those subjects with anterior AMI was higher than in those with inferior AMI (1.63 [1.13-2.44]) vs. 1.39 [1.08-2.33]; $\mathrm{p}=0.002)$ and LVEF was lower in anterior AMI than inferior AMI (40.1 vs 44.2\%, p=0.05). UII levels were not correlated with LVWMI $(r=-0.189$, $\mathrm{p}>0.202)$. However NT-BNP correlated with LVWMI $(\mathrm{r}=0.439, \mathrm{p}=0.0001)$ at all times. There was no correlation however between NT-BNP and UII ( $r=0.116, \mathrm{p}=0.332)$.

\section{UII as an independent predictor of adverse outcomes}

Patients incurring ACO had significantly lower plasma UII concentration compared to event free patients between 73-96hr (Median [Range], fmol/ml, 0.29 [0.29-4.21] vs. 2.13 [0.29_ 
30.0]; $P=0.006$ ). We examined this further and no significant difference was found in those patients who did mount a UII response to those who did not in terms of territory of infarct, STEMI vs. NSTEMI, total white cell count or background previous drug therapy (including previous use of aspirin, beta-blockers, statins, ACE inhibitors or angiotensin II receptor blockers).

When clinical and demographic characteristics were entered into a binary logistic regression model as predictors of ACO, UII (OR 0.002, $\mathrm{p}=0.027$ ) and NT-BNP (OR 9.38, $\mathrm{p}=0.004$ ) were independently predictive of ACO.

ROC curves for the prediction of ACO were constructed for the cohort of patients, both UII and NT-BNP being significantly different from the diagonal (UII (AUC 0.30; CI [0.18-0.42] $\mathrm{p}=0.007$ ); NT-BNP (AUC 0.82; CI [0.70-0.94] p=0.0001)). The AUC for UII was significantly less than the diagonal area of 0.5, reflecting that endpoints were associated with lower levels of UII. The AUC for the combination of UII and NT-BNP at predicting adverse outcome was 0.88 (CI [0.79-0.97], p=0.0001), which exceeded that of either peptide alone. Figure 3. Using a Cox proportional hazards model, UII (log rank 0.29, p=0.046) and NT-BNP (log rank 4.78, $\mathrm{p}=0.012$ ) between 73-96 hr were independent predictors of the combined endpoint. Kaplan-Meier survival analysis demonstrated that UII levels below the median were associated with poorer survival (log rank 5.72, $\mathrm{p}=0.022$, figure 4). Conversely NT-BNP levels above the median were associated with poorer survival over the study period $(\log \operatorname{rank} 8.93, p=0.003$, figure 5).

NT-BNP above the median was also related to death and heart failure (log rank 4.85, $\mathrm{p}=0.028$, log rank 5.26, $\mathrm{p}=0.022$ respectively, figure 6,7 ). UII did not show such a relationship to death or heart failure (log rank $0.3, \mathrm{p}=0.582, \log$ rank $0.38, \mathrm{p}=0.538$ respectively, graphs not shown). 


\section{Discussion}

Current methods of predicting risk of cardiovascular events in patients with AMI rely on clinical criteria, electrocardiographic criteria and echocardiography. These methods however are not very accurate at predicting adverse events. The use of biomarkers may be more informative with regards to risk of adverse events following an AMI.

This is the first study reporting plasma levels of UII in the acute phase of patients with AMI. Patients with AMI had significantly higher median UII levels than control subjects. Plasma UII levels in our control subjects were slightly higher than those reported by Richards et al (which employed ethanol precipitation of plasma and a radioimmunoassay) [12], but are similar to those values in a previous study by $\mathrm{Ng}$ et al (which employed $\mathrm{C}_{18}$ extracts of plasma and immunoluminometric assay) [8]. There are numerous biological and methodological factors that may influence the absolute values of the assay results. Some of the differences may be due to subject selection or assay antibody performance.

In our study UII did not show any correlation with peak troponin I and LVWMSI. This lack of correlation suggests that UII is not a marker of myocardial necrosis. UII may play an important role in the pathophysiology of atherosclerosis [13]. UII was found to be upregulated in the different leucocytes subpopulations, which propagate this disease state. Lymphocytes were found to be the largest producers of UII [13]. In contrast monocytes and macrophages were the largest producers of the UII receptor GPR14 [13]. This has also been borne out in a recent study showing elevated levels of UII in endothelial, myointimal and medial smooth muscle cells of atherosclerotic human coronary arteries [14]. Therefore UII may have a role in the pathophysiology of atherosclerosis.

This study is the first to report that plasma levels of UII were significantly lower in patients incurring combined endpoints of death, heart failure, MI or the need for urgent revascularisation than in those patients spared of these events. This paradoxical response to disease severity has been documented in the past for peptides such as myotrophin and urocortin 
$[15,16]$. It is inferred that elevated levels of UII in AMI may produce transient improvements in cardiac performance associated with a better prognosis. Our study demonstrated for the first time that plasma levels of UII independently predicted adverse outcome in patients presenting with AMI. In this present study we compared the utility of the natriuretic peptide NT-BNP in combination with UII for the prediction of composite endpoints. Although NT-BNP is a powerful maker of adverse events, both NT-BNP and UII are complementary and interactive prognostic indicators. The predictive value of the natriuretic peptide was enhanced markedly and complemented by plasma UII. Cox proportional hazard modelling confirmed these findings with UII and NT-BNP each independently predictive of combined endpoints. Our study suggests that UII measured at 73-96 hours rather than earlier in the acute phase, is a stronger predictor of poor clinical outcomes.

In this present research the survival analyses demonstrated that plasma levels of UII, below the median were associated with a poorer survival and increased likelihood of ACO. This suggests that those patients who fail to mount an adequate UII response in AMI have a poor prognosis, this is in contrast to our and others' results for NT-BNP $[2,17,18]$ and for numerous other peptides studied in the immediate post infarct period $[2,19,20]$. Elevated levels of UII may be cardioprotective at a time when the patient's cardiovascular system is most vulnerable. UII may be acting as a peripheral vasodilator post AMI acting to unload the infarcted myocardium, UII has previously been shown to have both a positive inotropic [5] and a peripheral vasodilator effect in resistance vessels [6]. This would then offer a possible explanation for the principal findings of our report in so far as those patients who fail to mount an adequate UII response then have a worse clinical outcome. Together UII and NT-BNP offer a practical early post-myocardial infarction risk stratification, which is more precise than either marker used alone. Further larger studies are required to validate these findings. UII or other analogues that are GPR14 agonists may also be a possible target for future therapy in patients who have had an AMI, similar to the therapeutic use of natriuretic peptides in heart failure [21]. 


\section{Limitations}

There are a number of limitations to this study. Our study consisted of a relatively small number of patients and events. Despite this limitation, our study reinforced previous findings relating to NT-BNP and adverse patient outcomes and established new relationships between the novel peptide UII and event-free survival. Further studies are required to investigate the long-term pattern of secretion after AMI, to understand whether UII has a beneficial or detrimental role to play in this disease process.

\section{Acknowledgments}

Dr Sohail Q Khan is supported by a British Heart Foundation Junior Research Fellowship (FS/03/028/15486). 


\section{References}

[1] Talwar S, Squire IB, Downie PF, McCullough AM, Campton MC, Davies JE, Barnett DB, Ng LL. Profile of plasma N-terminal proBNP following acute myocardial infarction; correlation with left ventricular systolic dysfunction. Eur Heart J 2000;21:1514-1521.

[2] Richards AM, Nicholls MG, Yandle TG, Frampton C, Espiner EA, Turner JG, Buttimore RC, Lainchbury JG, Elliott JM, Ikram H, Crozier IG, Smyth DW. Plasma N-terminal pro-brain natriuretic peptide and adrenomedullin: new neurohormonal predictors of left ventricular function and prognosis after myocardial infarction. Circulation 1998;97:1921-1929.

[3] Sabatine MS, Morrow DA, de Lemos JA, Gibson CM, Murphy SA, Rifai N, McCabe C, Antman EM, Cannon CP, Braunwald E. Multimarker approach to risk stratification in non-ST elevation acute coronary syndromes: simultaneous assessment of troponin I, C-reactive protein, and B-type natriuretic peptide. Circulation 2002;105:1760-1763.

[4] Ames RS, Sarau HM, Chambers JK, Willette RN, Aiyar NV, Romanic AM, Louden CS, Foley JJ, Sauermelch CF, Coatney RW, Ao Z, Disa J, Holmes SD, Stadel JM, Martin JD, Liu WS, Glover GI, Wilson S, McNulty DE, Ellis CE, Elshourbagy NA, Shabon U, Trill JJ, Hay DW, Ohlstein EH, Bergsma DJ, Douglas SA. Human urotensin-II is a potent vasoconstrictor and agonist for the orphan receptor GPR14. Nature 1999;401:282-286.

[5] Douglas SA, Ashton DJ, Sauermelch CF, Coatney RW, Ohlstein DH, Ruffolo MR, Ohlstein EH, Aiyar NV, Willette RN. Human urotensin-II is a potent vasoactive peptide: pharmacological characterization in the rat, mouse, dog and primate. J Cardiovasc Pharmacol 2000;36:S163-S166. 
[6] Stirrat A, Gallagher M, Douglas SA, Ohlstein EH, Berry C, Kirk A, Richardson M, MacLean MR. Potent vasodilator responses to human urotensin-II in human pulmonary and abdominal resistance arteries. Am J Physiol Heart Circ Physiol 2001;280:H925-H928.

[7] Russell FD, Molenaar P, O’Brien DM. Cardiostimulant effects of urotensin-II in human heart in vitro. Br J Pharm 2001;132:5-9.

[8] Ng LL, Loke I, O’Brien RJ, Squire IB, Davies JE. Plasma Urotensin in Human Systolic Heart Failure Circulation 2002;106:2877-2880.

[9] Schiller NB, Shah PM, Crawford M, DeMaria A, Devereux R, Feigenbaum H, Gutgesell H, Reichek N, Sahn D, Schnittger I, Silverman AH, Tajik AJ. Recommendations for quantitation of the left ventricle by two-dimensional echocardiography. American Society of Echocardiography Committee on Standards, Subcommittee on Quantitation of TwoDimensional Echocardiograms. J Am Soc Echocardiogr 1989;2:358-67

[10] Karl J, Borgya A, Gallusser A, Huber E, Krueger K, Rollinger W, Schenk J. Development of a novel, N-terminalproBNP (NT-proBNP) assay with a low detection limit. Scand J Clin Lab Invest Suppl 1999;230:177-181.

[11] Ng LL, O’Brien RJ, Demme B, Jennings S. A non-competitive immunochemiluminometric assay for Cardiotrophin-1 detects elevated plasma levels in human heart failure. Clin Sci 2002;102:411-416.

[12] Richards AM, Nicholls MG, Lainchbury JG, Fisher S, Yandle TG. Plasma urotensin II in heart failure. Lancet 2002;360:545-546 
[13] Bousette N, Patel L, Douglas SA, Ohlstein EH, Giaid A. Increased expression of urotensin II and its cognate receptor GPR14 in atherosclerotic lesions of the human aorta. Atherosclerosis 2004;176:117-123.

[14] Hassan GS, Douglas SA, Ohlstein EH, Giaid A. Expression of urotensin-II in human coronary atherosclerosis. Peptides 2005;26:2464-72.

[15] O’Brien RJ, Loke I, Davies JE, Squire IB, Ng LL. Myotrophin in Human Heart Failure. J Am Coll Cardiol 2003;42:719-25.

[16] Rademaker MT, Charles CJ, Espiner EA, Fisher S, Frampton CM, Kirkpatrick CM, Lainchbury JG, Nicholls MG, Richards AM, Vale WW. Beneficial haemodynamic, endocrine, and renal effects of urocortin in experimental heart failure: comparison with normal sheep. $J$ Am Coll Cardiol 2002;40:1495-505.

[17] Richards AM, Nicholls MG, Yandle TG, Frampton C, Espiner EA, Turner JG, Buttimore RC, Lainchbury JG, Elliott JM, Ikram H, Crozier IG, Smyth DW. Plasma N-terminal pro-brain natriuretic peptide and adrenomedullin: new neurohormonal predictors of left ventricular function and prognosis after myocardial infarction. Circulation 1998;97:1921-9.

[18] Omland T, Persson A, Ng L, O'Brien R, Karlsson T, Herlitz J, Hartford M, Caidahl K Nterminal pro-B-type natriuretic peptide and long-term mortality in acute coronary syndromes. Circulation 2002;106:2913-8.

[19] de Lemos JA, Morrow DA, Bentley JH, Omland T, Sabatine MS, McCabe CH, Hall C, Cannon CP, Braunwald E. The prognostic value of B-type natriuretic peptide in patients with 
acute coronary syndromes. $N$ Engl J Med 2001;345:1014-2.

[20] de Lemos JA, Morrow DA, Sabatine MS, Murphy SA, Gibson CM, Antman EM, McCabe CH, Cannon CP, Braunwald E. Association between plasma levels of monocyte chemoattractant protein-1 and long-term clinical outcomes in patients with acute coronary syndromes. Circulation 2003;107:690-5.

[21] Silver MA, Horton DP, Ghali JK, Elkayam U. Effect of nesiritide versus dobutamine on short-term outcomes in the treatment of patients with acutely decompensated heart failure. $J$ Am Coll Cardiol 2002;39:798-803. 


\section{Figure Legends}

Figure 1 Time dependent changes in UII (mean \pm SEM) after onset of AMI

Figure 2 Time dependent changes in NT-BNP (mean \pm SEM) after onset of AMI

Figure 3 Combined Receiver Operating Curve comparing NT-BNP, UII and the combined predicted probabilities of Adverse Clinical Outcome

Figure 4 Kaplan-Meier Curve: Time to Adverse Clinical Outcome related to median serum UII Figure 5 Kaplan-Meier Curve: Time to Adverse Clinical Outcome related to median serum NT-BNP

Figure 6 Kaplan-Meier Curve: Time to death related to median serum NT-BNP

Figure 7 Kaplan-Meier Curve: Time to readmission with heart failure related to median serum NT-BNP 
Table 1: Characteristics of Patients \& Controls in the Study. Values are means (SD) or numbers (percentage)

\begin{tabular}{|c|c|c|}
\hline & Controls & AMI Patients \\
\hline Number & 21 & 129 \\
\hline Age (in years) & $60.4 \pm 11.6$ & $63.6 \pm 12.4$ \\
\hline \multicolumn{3}{|l|}{ Previous Medical History } \\
\hline Myocardial infarction & None & $15(11.6)$ \\
\hline Angina Pectoris & None & $22(17.1)$ \\
\hline Hypertension & None & $53(41.1)$ \\
\hline Diabetes mellitus & None & $30(23.3)$ \\
\hline Hypercholesterolaemia & None & $40(31.0)$ \\
\hline Obesity & None & $11(8.5)$ \\
\hline Current Smokers & None & $52(40.3)$ \\
\hline ST-elevation AMI & None & $109(84.5)$ \\
\hline Non-ST-elevation AMI & None & $20(15.5)$ \\
\hline \multicolumn{3}{|l|}{ Territory of Infarct } \\
\hline Anterior & & $57(44.2)$ \\
\hline Inferior & & $60(46.5)$ \\
\hline Other/undetermined & & $12(9.3)$ \\
\hline \multicolumn{3}{|l|}{ Killip Class on Admission } \\
\hline $\mathrm{I}$ & & 69 (53.5) \\
\hline II & & $57(44.2)$ \\
\hline III & & $2(1.6)$ \\
\hline IV & & $1(0.8)$ \\
\hline Peak CK & & $1312.9 \pm 1256.1$ \\
\hline Peak Troponin I & & $26.2 \pm 38.8$ \\
\hline
\end{tabular}


Figures

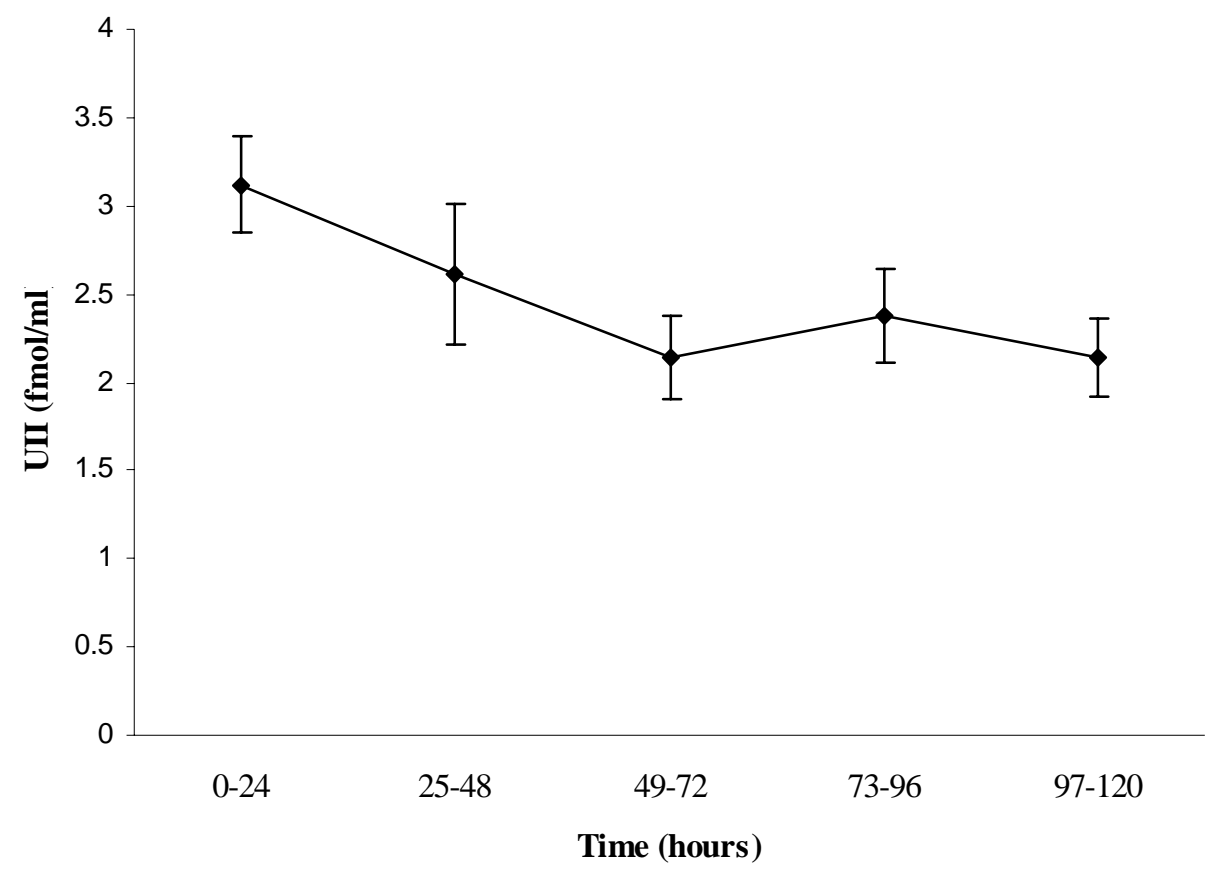

Figure 1 


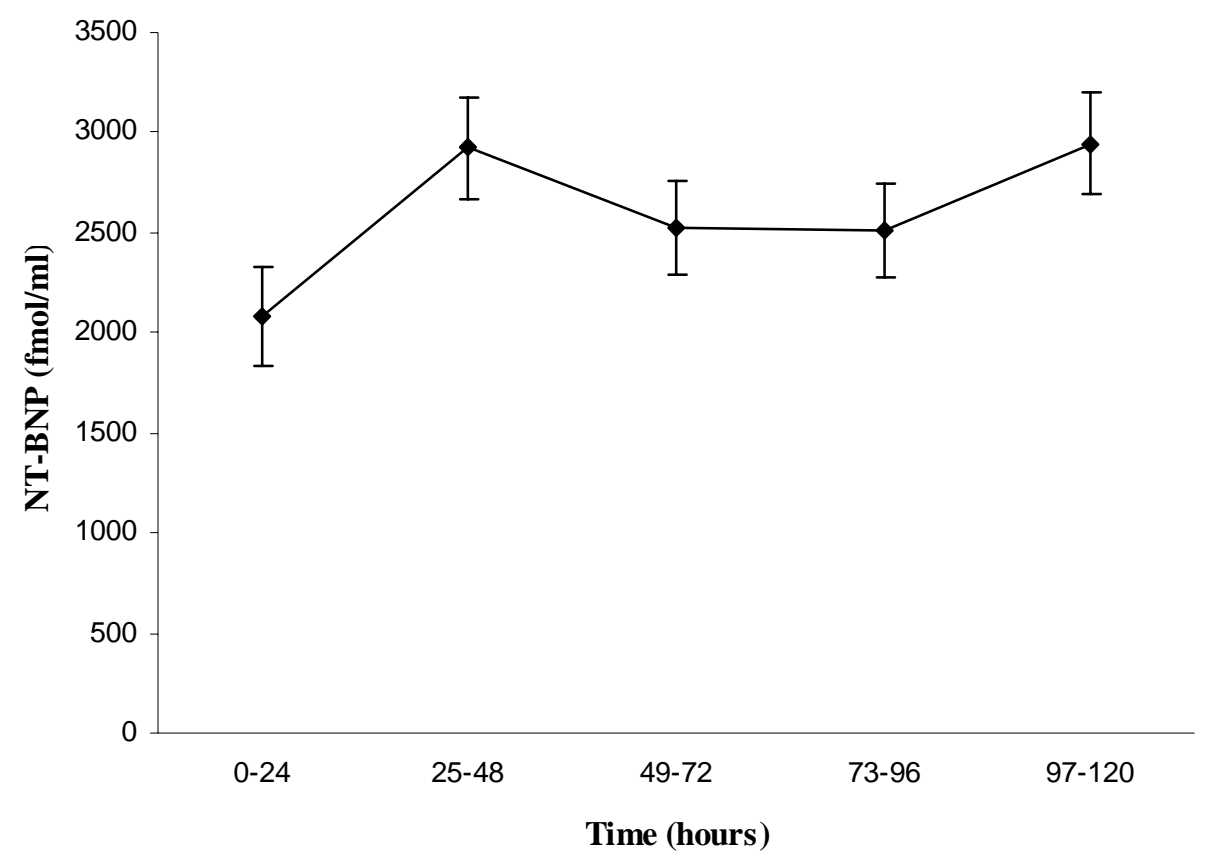

Figure 2 


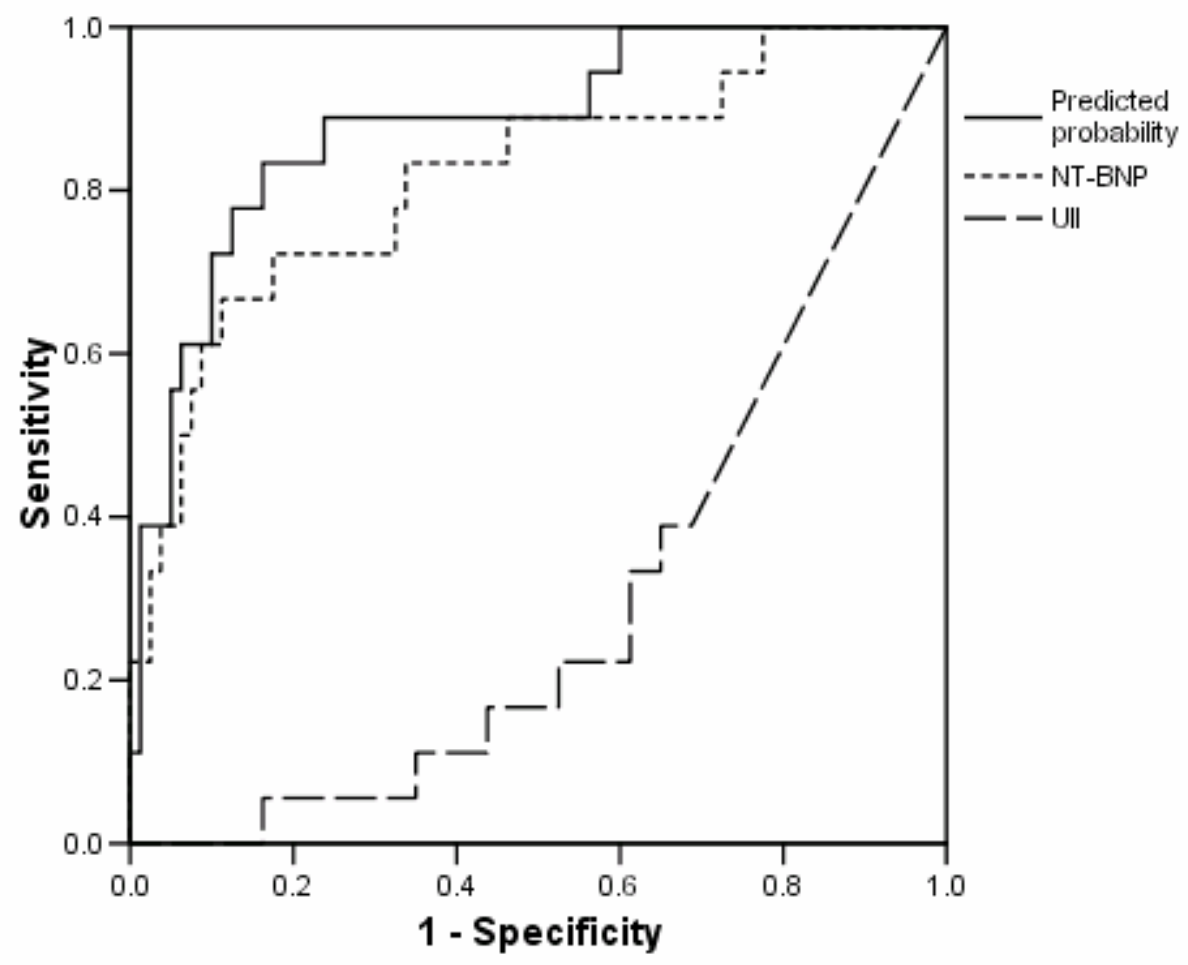

Figure 3 


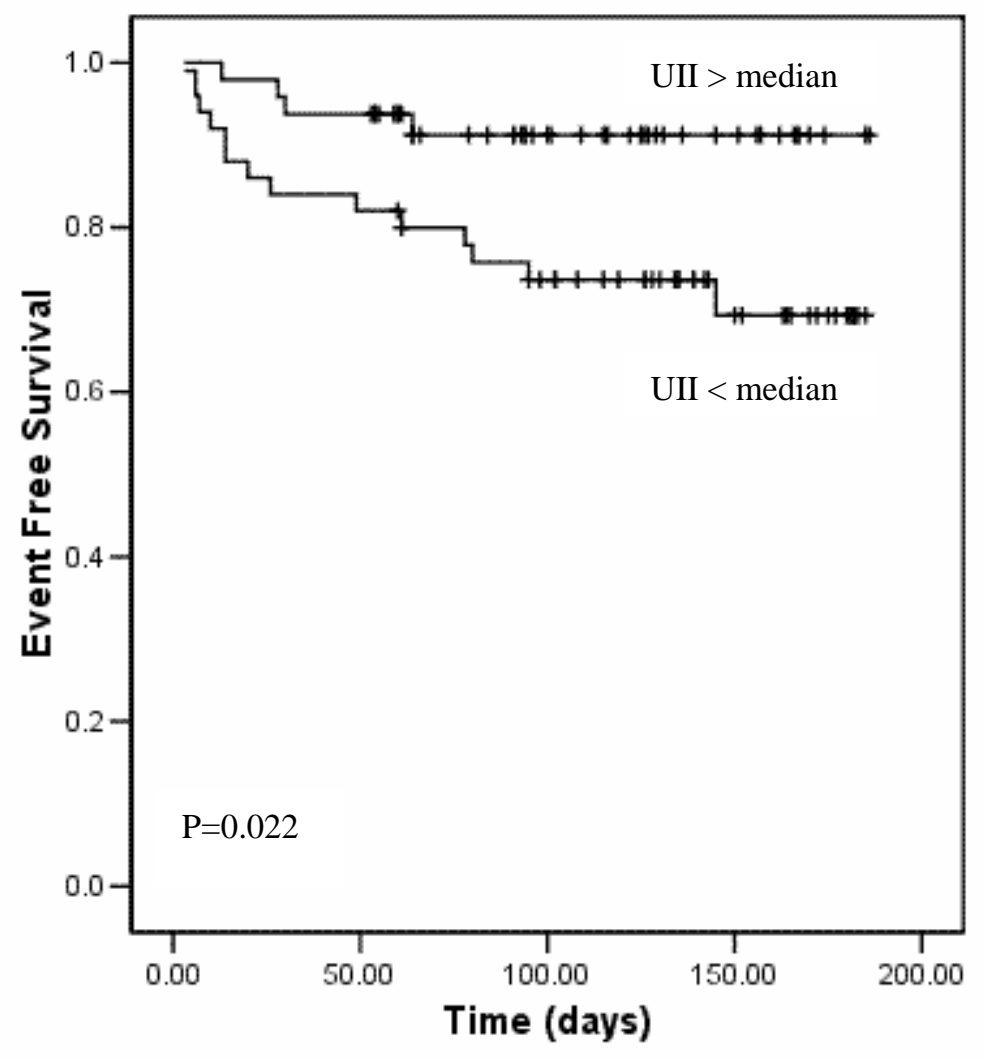

Figure 4 


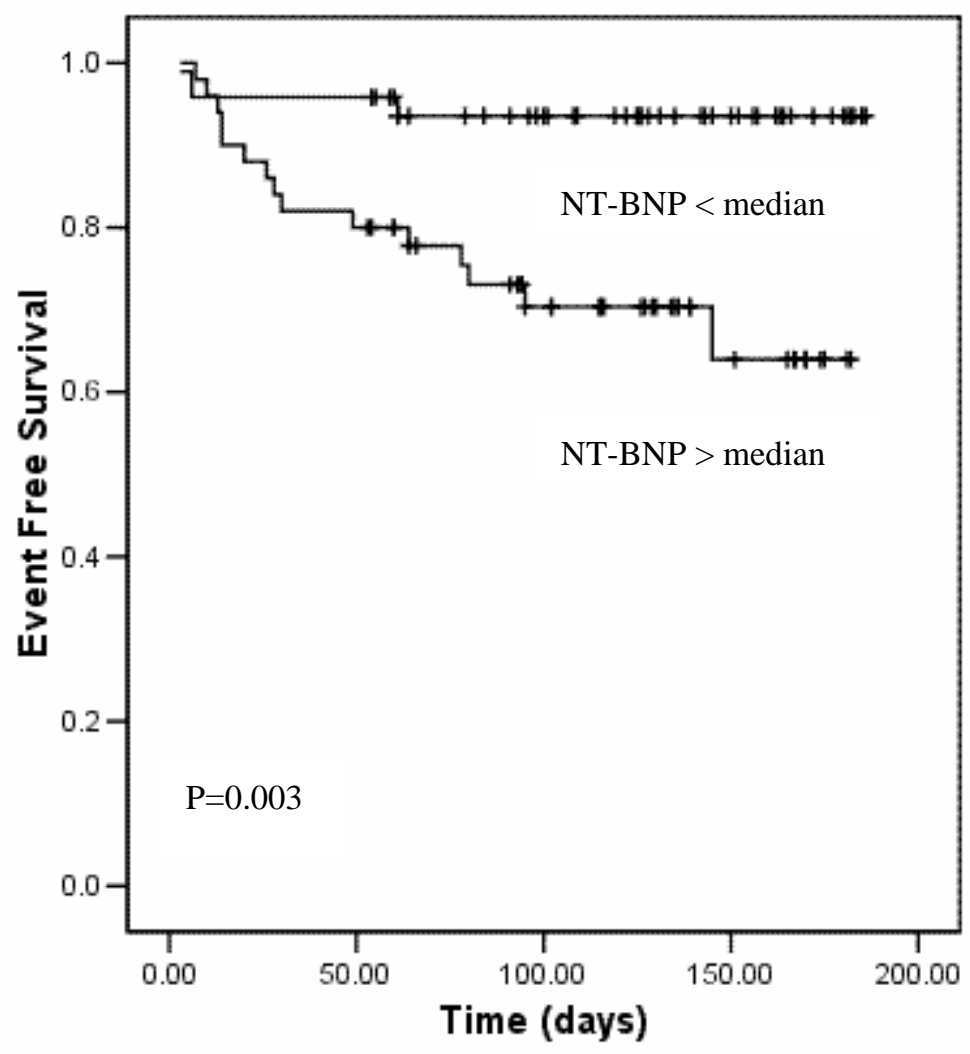

Figure 5 


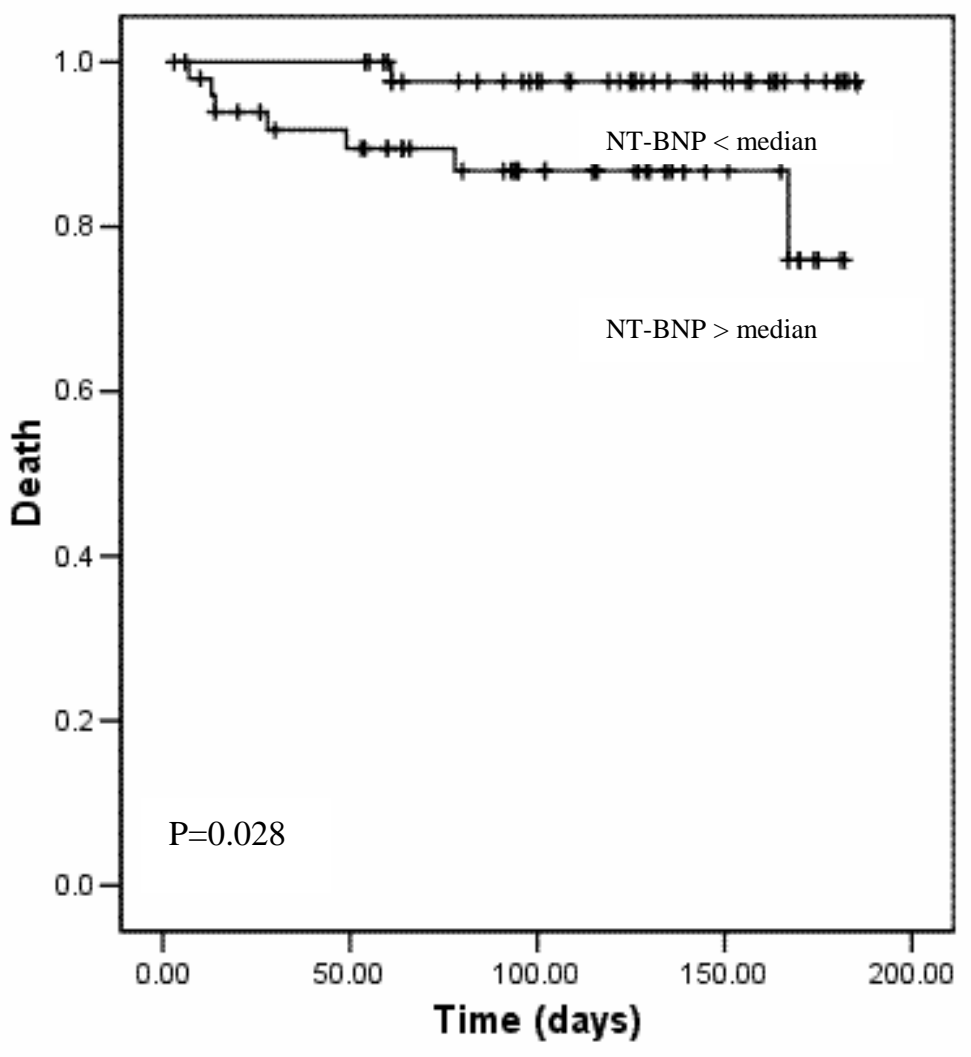

Figure 6 


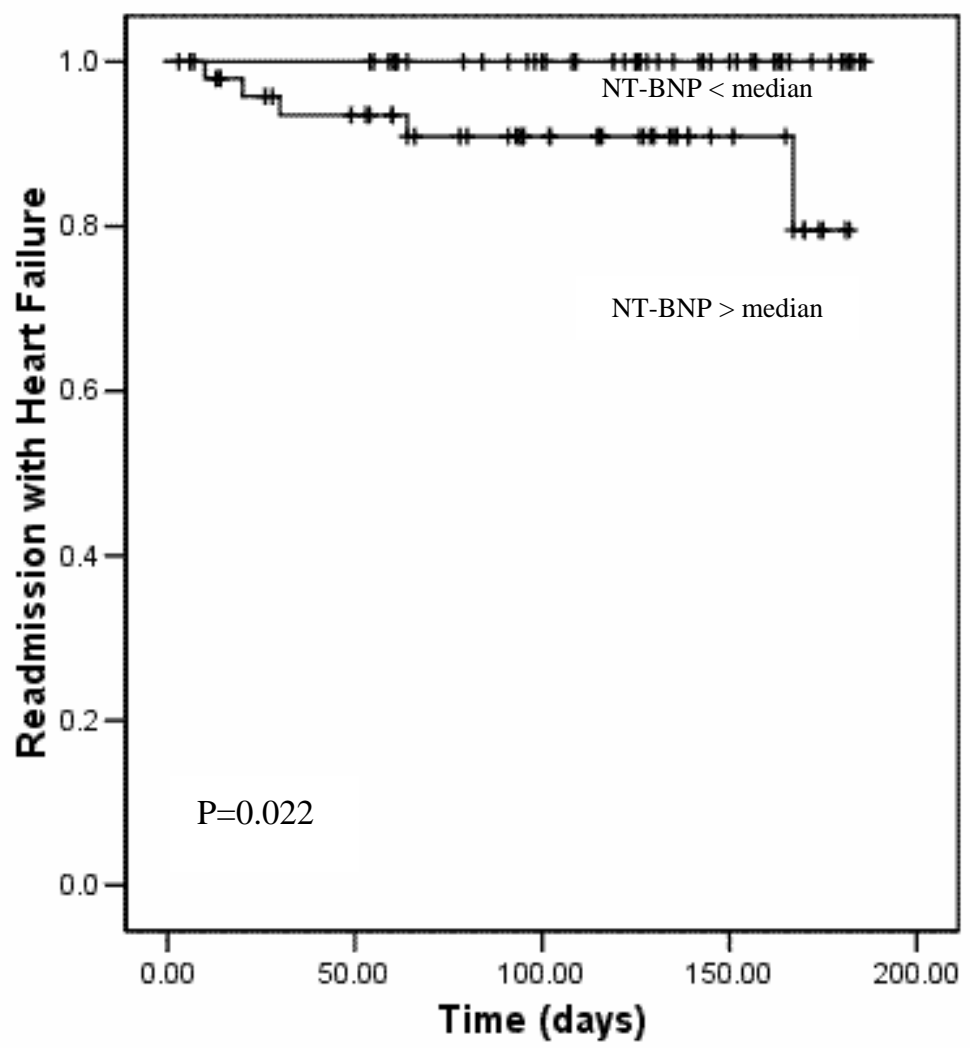

Figure 7 